\title{
Whey Protein Derived Mouthdrying Found to Relate Directly to Retention Post Consumption but Not to Induced Differences in Salivary Flow Rate
}

\author{
Victoria Norton, Stella Lignou and Lisa Methven * (D)
}

check for

updates

Citation: Norton, V.; Lignou, S.; Methven, L. Whey Protein Derived Mouthdrying Found to Relate Directly to Retention Post Consumption but Not to Induced Differences in Salivary Flow Rate. Foods 2021, 10, 587. https://doi.org/ 10.3390 /foods 10030587

Academic Editors: Susana Soares and Victor de Freitas

Received: 9 February 2021

Accepted: 8 March 2021

Published: 11 March 2021

Publisher's Note: MDPI stays neutral with regard to jurisdictional claims in published maps and institutional affiliations.

Copyright: (c) 2021 by the authors. Licensee MDPI, Basel, Switzerland. This article is an open access article distributed under the terms and conditions of the Creative Commons Attribution (CC BY) license (https:// creativecommons.org/licenses/by/ $4.0 /)$
Department of Food and Nutritional Sciences, Harry Nursten Building, University of Reading, Whiteknights, Reading RG6 6DZ, UK; v.l.norton@pgr.reading.ac.uk (V.N.); s.lignou@reading.ac.uk (S.L.)

* Correspondence: l.methven@reading.ac.uk; Tel.: +44-(0)118-378-8714

\begin{abstract}
Whey protein is fortified into beverages to provide functional benefits, however, these beverages are considered mouthdrying. To date whey protein derived mouthdrying has not been quantified using a 'physical measure' in parallel with rated perception. Saliva flow could also relate to whey protein derived mouthdrying, however this has not been previously tested as an intervention. Accordingly, volunteers $(n=40)$ tested mouthdrying in different whey beverages and the sensory profile was evaluated by a trained sensory panel $(n=10)$. Volunteers also rated mouthdrying combined with collection of saliva samples post beverage consumption to measure retention to the oral cavity. To modulate saliva flow rate, volunteers both chewed on parafilm (to increase saliva flow) and used cotton wool (to remove saliva) before tasting beverages and rating mouthdrying. Both the volunteers and sensory panel rated whey protein beverages (WPB) as significantly more mouthdrying than the control beverage (whey permeate). The significantly higher rating of mouthdrying from the volunteers coincided with significantly higher protein concentration in saliva samples post WPB consumption, supporting mucoadhesion as the mechanism. Modulating saliva flow did not lead to any difference in rated mouthdrying and future work would be beneficial to evaluate further the influence of natural variation in salivary flow rate.
\end{abstract}

Keywords: mucoadhesion; whey protein; mouthdrying; whey permeate; saliva flow

\section{Introduction}

Protein needs are suggested to increase with age (1.0-1.2 g/ kg/day) despite the current UK reference nutrient intake (RNI) for adults only being $0.75 \mathrm{~g} / \mathrm{kg} /$ day [1,2]. Accordingly, there is an increasing emphasis on improving protein intake across the lifespan to offset potentially associated health conditions, slow the rate of muscle decline and promote healthy ageing $[3,4]$. Protein consumption is also associated with a number of positive benefits, such as improved health outcomes, appetite regulation, weight management and enhanced sports performance $[1,5]$. Oral nutritional supplements (ONS) and protein fortified products are often used to improve energy and protein intake especially in older adults. Whey protein is commonly fortified into these products due its associated functional benefits, such as higher leucine content and quicker digestion and absorption kinetics [6]. Products need to be an appropriate portion size, palatable, energy dense and appetising to increase successfully nutritional intake [7].

Despite the widespread recognised benefits of ONS consumption, product compliance and consumption of adequate product to meet individual needs are considered limiting factors in maximising such benefits, together with related cost and waste ramifications [7-9]. In addition, product palatability (for example, appearance, aroma, flavour, texture, and mouthfeel) can be a key driver of product acceptability by consumers [3]. More specifically, texture is suggested to provide a key role in food preferences, where texture awareness can relate to product expectation [10]. This is particularly relevant for dairy products as 
mouthfeel attributes are commonly associated with product dislike, typically build with repeated consumption and are challenging to define [9,11-15]. Food and beverage matrices fortified with whey protein have also resulted in negative mouthfeel attributes such as mouthdrying, hardness, slower melt rate, teeth packing, increased crumb size, chalky, mouthcoating, grainy, rough and dense [15-18]. Previously, our research group proposed whey permeate (a deproteinised whey powder) as a suitable non-protein control to fortify cakes and beverages and to provide comparisons with whey protein fortification in order to investigate mouthdrying and mucoadhesion respectively $[16,19]$. However, other previous studies into mouthdrying within whey protein beverage (WPB) models have typically been carried out without a non-protein control and are therefore limited in that they unable to prove if the protein within WPB is causing the mouthdrying. Understanding and addressing these proposed causes of poor compliance is key to maximising benefits from such products.

Dairy products have been associated with a 'textural defect' [20] often referred to as astringency, drying and mouthdrying. However, astringency is as 'a result of exposure to substances such as alums or tannins' [21] which are not usually present in whey protein. Accordingly, the term mouthdrying (a drying sensation in the mouth during or after consumption of a product) is considered more appropriate in the context of dairy products. The proposed causes of such whey protein derived mouthdrying remain unconfirmed and form part of our current investigation [19]. Our research group proposed mucoadhesion as a probable cause of whey protein derived mouthdrying (especially from neutral $\mathrm{pH}$ WPB), however further proof is required.

Mucoadhesion has been studied in drug delivery and food systems [22-26] and is considered in the context of this paper as the binding or sticking (retention) of whey proteins to the oral cavity [15]. Recently, our research group demonstrated that protein is considered to adhere to the oral cavity (mucoadhesion) to a greater extent post WPB consumption compared with a whey permeate beverage (WPeB), and mucoadhesion is considered to increase with age [19]. Despite establishing a valid 'physical measure' to measure mucoadhesion [19], a potential limitation of this previous study was that the link between mucoadhesion and mouthdrying within the same method was not investigated.

Saliva is associated with a number of key functions, such as lubrication, food clearance, taste and mouthfeel, digestion and oral health [27]. In addition, salivary flow rates are considered to reduce with age [28] and could alter sensory perception [29-34]. However, previous research into this has so far been relatively inconclusive as regards the effect on subsequent perception of protein products $[16,19,35]$ and needs further investigation. Accordingly, understanding salivary flow changes, and its relevance to sensory perception and food acceptance, is of growing relevance.

Previous research indicates mouthdrying and mucoadhesion are present within dairy beverages and increase with consumers' age $[19,36]$. However, trying to prove that the perception of mouthdrying increases with age has produced mixed results, potentially due to the lack of sensitivity of rating scales (i.e., the generalised Labelled Magnitude Scale, gLMS) compared with discrimination testing in detecting mouthdrying in older adults $[19,36]$. Therefore, our study will evaluate mouthdrying using both tests to explore further these concerns. The link between whether greater WPB retention results in increased WPB mouthdrying perception and the influence of salivary flow on such perception, are both relatively unclear. Accordingly, further investigation is necessary to understand these phenomena for the benefit of older adults in the future. This study hypothesises that (a) modulating salivary flow will alter mouthdrying perception and (b) oral retention is directly related to whey protein derived mouthdrying. In order to evaluate these hypotheses mouthdrying was evaluated via quantitative descriptive analysis (QDA), 2Alternative Forced Choice Test (2-AFC) and gLMS. This study had the following objectives (a) to provide more conclusive evidence that mucoadhesion and mouthdrying of WPBs are intrinsically linked and (b) to test whether modulating saliva flow can influence perceived mouthdrying of beverages. 


\section{Materials and Methods}

\subsection{Study Overview}

Forty volunteers $(24.9 \pm 3.4$ years, healthy) completed a single blinded randomised crossover trial over two study visits (Table 1). Power calculations (alpha risk $=0.05$ and 80\% power) were used to calculate the subject size based on previous work in WPBs [19] using mouthdrying intensity ratings (0-100) as the primary outcome measure and, assuming a difference of 16 and standard deviation of 23, indicating the lowest sample size of 32 . The study was conducted in compliance with current COVID-19 guidelines at the time (August and September 2020; with appropriate risk assessments and social distancing). The study was fully explained to the volunteers and their informed written consent was obtained prior to their participation. In addition, it was made clear that all data would be anonymised and kept confidential, as well as there being a right to withdraw. The study received a favourable opinion for conduct from the University of Reading, School of Chemistry, Food and Pharmacy Research Ethics Committee (SCFP 32/20) and the study was registered on the clinical trials database (www.clinicaltrials.gov (accessed on 11 August 2020) as NCT04507399). Volunteers were screened to ensure they met inclusion criteria (minimal medication, no COVID-19 symptoms or not having had COVID-19 within the last 4 weeks, not smokers, with no known allergies or intolerances to food, not with diabetes nor cancer and not having had oral surgery or a stroke). The study visits (Figure 1) were held at the Sensory Science Centre, University of Reading.

Table 1. Summary of volunteers' sex, medication and salivary flow rates categories (' $n$ ' and '\%' indicate number and percentage). Saliva flow categories were defined as below (or equal to) or above the median (missing data $n=1$ ).

\begin{tabular}{lcc}
\multicolumn{1}{c}{ Variable } & Total $(n=40)$ & \\
& $n$ & $\%$ \\
\hline Sex & 12 & 30 \\
$\quad$ Male & 28 & 70 \\
$\quad$ Female & 2 & 5 \\
Medication & 38 & 95 \\
$\quad$ Yes & & \\
$\quad$ No & 19 & 49 \\
Unstimulated Saliva Flow (mL/min) & 20 & 51 \\
$\quad$ Low (0.10-0.70) & & 54 \\
$\quad$ High (0.70-1.4) & 21 & 46 \\
Stimulated Saliva Flow (mL/min) & 18 & \\
$\quad$ Low (0.78-2.23) & & \\
$\quad$ High (2.23-4.08) & & \\
\hline
\end{tabular}

\section{Study Visit One}

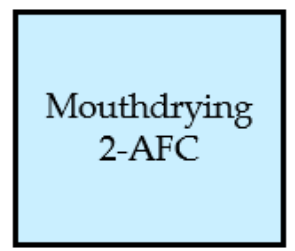

\section{Whey beverage} perception and liking
Modulating saliva flow and mouthdrying perception

\section{Study Visit Two}

Saliva samples post beverage consumption and mouthdrying perception

Figure 1. Study Overview (2-AFC: two alternative forced choice). 


\subsection{Materials}

Two whey powders were used: whey protein concentrate (WPC) (Volactive UltraWhey 80; minimum protein content $80 \%$, remainder as lactose, fat, moisture and ash) and whey permeate (WPe) (Volactose Taw Whey Permeate; minimum lactose content $89 \%$, remainder ash, moisture, protein and fat) (Volac International Ltd., Royston, UK). Sucrose (Caster sugar, Tate \& Lyle, London, UK) and vanilla extract (Nielsen-Massey, The Netherlands) were sourced from Sainsbury's (Reading, UK). Parafilm ${ }^{\circledR}$, Bradford reagent (0.1-1.4 mg/mL) and protein standard (Bovine Serum Albumin, BSA, $2 \mathrm{mg} / \mathrm{mL}$ ) were purchased from Sigma-Aldrich (Dorset, UK).

\subsection{Model Beverage Preparation}

Four different whey beverages were tested: (1) a control whey permeate beverage (WPeB; $4 \% w / v$, WPe powder in deionised water) and (2) a whey protein beverage (WPB; $10 \% w / v$, WPC powder in deionised water). The rationale was as outlined in our previous work [19]. WPe provides a non-protein whey control at a concentration selected to keep the lactose content below sweet taste recognition and WPC concentration is relevant to commercial products as well as commonly utilised in WPB testing [15,37-39]. In addition, sample palatability was improved by adding sucrose and vanilla as previous work highlighted that unsweetened WPBs were rated as disliked moderately (mean 3 on 9-point hedonic scale) [19]. This resulted in (3) a sweetened control whey permeate beverage (WPeBS; $4 \% w / v$ WPe, $1.49 \% w / v$ sucrose, $1 \% w / v$ vanilla extract) and (4) a sweetened whey protein beverage (WPBS; $10 \% w / v$ WPC powder, $2 \% w / v$ sucrose, $1 \% w / v$ vanilla extract). Less sucrose was added to the WPeBS compared with the WPBS due to the lactose content of the WPe; they were matched on relative sweetness. Formulations are summarised in Table 2. Samples were prepared simultaneously and stirred (magnetic stirrers at medium speed; Stuart ${ }^{\mathrm{TM}} \mathrm{SM}$, Cole-Parmer, Staffordshire, UK) for 90-min at room temperature $\left(21.8 \pm 2.0^{\circ} \mathrm{C}\right)$. Samples were left to hydrate overnight at $4{ }^{\circ} \mathrm{C}$ before being served to volunteers at room temperature.

Table 2. Composition of whey beverages (WPeB: whey permeate beverage; WPeBS: whey permeate beverage sweetened; WPB: whey protein beverage; WPBS: whey protein beverage sweetened) per $10 \mathrm{~mL}$ (as tasted) and per $100 \mathrm{~mL}$.

\begin{tabular}{|c|c|c|c|c|c|c|c|c|}
\hline & \multicolumn{2}{|c|}{ WPeB } & \multicolumn{2}{|c|}{ WPeBS } & \multicolumn{2}{|c|}{ WPB } & \multicolumn{2}{|c|}{ WPBS } \\
\hline & Per $10 \mathrm{~mL}$ & Per $100 \mathrm{~mL}$ & Per $10 \mathrm{~mL}$ & Per $100 \mathrm{~mL}$ & Per $10 \mathrm{~mL}$ & Per 100 mL & Per $10 \mathrm{~mL}$ & Per $100 \mathrm{~mL}$ \\
\hline Energy (kcal) & 1.5 & 14.7 & 2.4 & 23.7 & 4.0 & 39.7 & 5.1 & 50.7 \\
\hline Fat $(\mathrm{g})$ & 0.0008 & 0.008 & 0.0008 & 0.008 & 0.07 & 0.7 & 0.07 & 0.7 \\
\hline of which saturates $(\mathrm{g})$ & - & - & - & - & 0.03 & 0.3 & 0.03 & 0.3 \\
\hline Carbohydrate $(\mathrm{g})$ & 0.4 & 3.6 & 0.5 & 5.1 & 0.04 & 0.4 & 0.2 & 2.4 \\
\hline of which sugars (g) & 0.4 & 3.6 & 0.5 & 5.1 & 0.04 & 0.4 & 0.2 & 2.4 \\
\hline Protein $(\mathrm{g})$ & 0.01 & 0.1 & 0.01 & 0.1 & 0.8 & 8.2 & 0.8 & 8.2 \\
\hline Moisture (g) & 0.004 & 0.04 & 0.004 & 0.04 & 0.05 & 0.5 & 0.05 & 0.5 \\
\hline Ash (g) & 0.02 & 0.2 & 0.02 & 0.2 & 0.04 & 0.4 & 0.04 & 0.4 \\
\hline
\end{tabular}

Composition was calculated from technical data sheets of ingredients used. The viscosity of beverages was measured and considered broadly similar, as outlined in Figure S1.

\subsection{Sensory Methods}

All sensory evaluation (trained sensory panel and volunteers) was carried out under red lights (to mask minor visual differences between samples) in isolated booths using Compusense Cloud Software (Version 21.0.7713.26683, Compusense, ON, Canada). Palate cleansing between samples used filtered warm water [36]. All samples were presented at the same time on different trays (due to COVID-19 serving restrictions) but tasted in a randomly allocated sequential balanced order, and coded with a random three-digit number. Samples $(10 \mathrm{~mL})$ were presented in black plastic cups ( $25 \mathrm{~mL}$; opaque) (BB Plastics, West Yorkshire, UK). 


\subsection{Sensory Profile}

Quantitative descriptive analysis ( $\left(\mathrm{QDA}^{\mathrm{TM}}\right)$ [40] was used to determine the sensory differences between the whey beverages, as well as to quantify the attribute changes arising from the addition of sucrose and vanilla. All panellists $(n=10$; 9 female and 1 male, screened and trained) had a minimum of one years' experience and at least six hours training involving whey beverages. Both trained panel and study volunteers had the same samples (WPeB, WPeBS, WPB and WPBS). The trained panel developed a consensus vocabulary (adapted from previous work [15]) identifying 21 attributes as outlined in Table 3. Appearance was not evaluated due to potential visual differences between samples which could lead to bias evaluation; accordingly to address these concerns samples were presented in opaque black plastic cups and under red lights to minimise such differences between samples. Panellists evaluated the samples in duplicate (in different sessions) using unstructured line scales (0-100) with appropriate anchors.

\subsection{Mouthdrying 2-Alterative Forced Choice Test (2-AFC)}

Volunteers were provided with clear instructions, presented with two samples and asked which sample was more mouthdrying via a single paired comparison test comparing WPeBS with WPBS (in accordance with ISO 5495:2005) [41]. The rationale for using a 2-AFC test was due to its simplicity and ability to detect small differences between samples; it had previously been used successfully to find such differences between products $[36,42]$.

\subsection{Whey Beverage Individual Perception and Liking}

Volunteers rated liking (9-point hedonic scale), easiness to drink and swallow (5-point category scale), attribute perception (logarithmic scale (gLMS) with descriptors for intensity of sweetness, thickness and mouthdrying attributes), appropriateness of attribute level (Just-About-Right, JAR; 5-point hedonic JAR scale), preference and consumption of whey beverages (ranked preference; a series of 2-AFC tests to assess paired preference; frequency of consumption on 6-point category scale) and provided comments relating to flavour and texture. All volunteers completed a training exercise (Figure S2; rating 15 remembered or imagined sensations adapted from previous work [43]) to become familiar with gLMS [44] as a scale. Volunteers had a break ( $45 \mathrm{~s}$ ) between samples during which they cleansed their palate by drinking warm filtered water.

\subsection{Modulating Saliva Flow and Mouthdrying Perception}

To understand the role of saliva on mouthdrying perception (Figure 2); saliva flow was modulated for 2 -min by either decreasing saliva flow via placing $4 \times$ cotton wool rolls $(40 \mathrm{~mm} \times 10 \mathrm{~mm}$ ) (two on each side split between the upper and lower jar) within the mouth or increasing saliva flow by chewing on parafilm ${ }^{\circledR}(5 \times 5 \mathrm{~cm})$ (adapted from previous work [31,45]). Volunteers were given four $10 \mathrm{~mL}$ beverage samples $(2 \times$ WPeBS and $2 \times$ WPBS) and immediately following consumption scored the sample for mouthdrying on a gLMS as well as scoring the aftereffects of mouthdrying at $15 \mathrm{~s}, 30 \mathrm{~s}, 60 \mathrm{~s}$ and $120 \mathrm{~s}$ time intervals post consumption. Volunteers also had an enforced 3-min break between samples (rationale based on initial testing within our lab and protein concentration in saliva samples post WPB consumption being considered to have plateaued within 3-min) [15,19], where they swilled and consumed warm filtered water. 


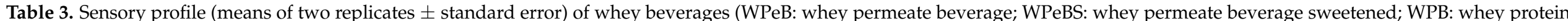
beverage; WPBS: whey protein beverage sweetened).

\begin{tabular}{|c|c|c|c|c|c|c|c|}
\hline Modality & Attribute & Reference and/or Description & WPeB & WPeBS & WPB & WPBS & Significant of Sample ( $p$ Value) \\
\hline \multirow[t]{4}{*}{ Aroma } & Cooked milk & Heated pasteurised semi-skimmed milk & $9.2 \pm 2.7$ & $8.1 \pm 2.9$ & $20.6 \pm 4.4$ & $18.4 \pm 3.9$ & 0.12 \\
\hline & Powdered milk (wet) & $\begin{array}{l}\text { Skimmed milk powder }(10 \% w / v \text {, skimmed milk powder in } \\
\text { deionised water) }\end{array}$ & $7.7 \pm 2.6$ & $20.7 \pm 3.9$ & $11.9 \pm 3.9$ & $17.8 \pm 3.8$ & 0.07 \\
\hline & Whey isolate & $\begin{array}{l}\text { Volactive Ultra-Whey } 90 \text { Instant (5\% } w / v \text {, WPI powder in } \\
\text { deionised water) }\end{array}$ & $8.8 \pm 2.4$ & $6.3 \pm 3.8$ & $7.6 \pm 2.8$ & $10.1 \pm 3.7$ & 0.80 \\
\hline & Vanilla & Vanilla extract (Nielsen-Massey) & $0.7 \pm 1.9^{\mathrm{c}}$ & $42.1 \pm 5.1^{\mathrm{a}}$ & $1.1 \pm 1.9^{\mathrm{c}}$ & $31.8 \pm 4.8^{\mathrm{b}}$ & $<0.0001$ \\
\hline \multirow[t]{9}{*}{ Flavour } & Sour & Citric acid $(0.76 \mathrm{~g} / \mathrm{L})$ & $17.5 \pm 3.5^{\mathrm{a}, \mathrm{b}}$ & $8.0 \pm 4.9^{b}$ & $23.9 \pm 4.0^{\mathrm{a}}$ & $17.5 \pm 4.9^{\mathrm{a}, \mathrm{b}}$ & 0.048 \\
\hline & Metallic & Iron (II) sulphate heptahydrate $(0.0036 \mathrm{~g} / \mathrm{L})$ & $8.7 \pm 3.3$ & $8.2 \pm 2.5$ & $10.1 \pm 3.7$ & $5.9 \pm 3.7$ & 0.44 \\
\hline & Salty & Sodium chloride $(1.19 \mathrm{~g} / \mathrm{L})$ & $7.7 \pm 2.2$ & $5.0 \pm 2.2$ & $9.4 \pm 2.6$ & $6.3 \pm 1.9$ & 0.27 \\
\hline & Sweet & Sucrose $(5.76 \mathrm{~g} / \mathrm{L})$ & $19.6 \pm 3.0^{\mathrm{b}}$ & $52.2 \pm 6.4^{\mathrm{a}}$ & $12.1 \pm 2.5^{\mathrm{b}}$ & $46.6 \pm 5.8^{\mathrm{a}}$ & $<0.0001$ \\
\hline & Cooked butter & Melted unsalted butter & $9.6 \pm 3.0$ & $3.3 \pm 6.6$ & $9.8 \pm 2.6$ & $9.7 \pm 6.0$ & 0.43 \\
\hline & Cooked milk & Heated pasteurised semi-skimmed milk & $15.2 \pm 3.3$ & $12.1 \pm 2.9$ & $24.4 \pm 4.0$ & $24.3 \pm 4.4$ & 0.17 \\
\hline & Powdered milk (wet) & $\begin{array}{l}\text { Skimmed milk powder }(10 \% w / v \text {, skimmed milk powder in } \\
\text { deionised water) }\end{array}$ & $6.1 \pm 3.4$ & $16.4 \pm 3.8$ & $14.3 \pm 4.3$ & $19.2 \pm 4.1$ & 0.12 \\
\hline & Whey isolate & $\begin{array}{c}\text { Volactive Ultra-Whey } 90 \text { Instant }(5 \% w / v \text {, WPI powder in } \\
\text { deionised water) }\end{array}$ & $14.7 \pm 2.8$ & $8.6 \pm 3.8$ & $17.5 \pm 3.4$ & $14.2 \pm 4.1$ & 0.32 \\
\hline & Vanilla & Vanilla extract (Nielsen-Massey) & $2.5 \pm 2.6^{\mathrm{b}}$ & $41.3 \pm 5.3^{\mathrm{a}}$ & $0.0 \pm 2.9^{b}$ & $33.5 \pm 5.0^{\mathrm{a}}$ & $<0.0001$ \\
\hline \multirow{3}{*}{ Mouthfeel } & Body & Fullness of sample & $21.0 \pm 3.3^{b}$ & $21.4 \pm 4.2^{b}$ & $31.2 \pm 4.6^{\mathrm{a}}$ & $31.4 \pm 4.2^{\mathrm{a}}$ & 0.006 \\
\hline & Chalky & Dry fine insoluble powder & $4.3 \pm 3.4^{\mathrm{b}}$ & $3.9 \pm 3.1^{b}$ & $27.3 \pm 5.1^{\mathrm{a}}$ & $16.8 \pm 3.8^{\mathrm{a}}$ & 0.0003 \\
\hline & Mouthdrying & Drying sensation in the mouth & $26.5 \pm 4.1^{\mathrm{c}}$ & $30.3 \pm 4.5^{\mathrm{c}}$ & $51.2 \pm 6.3^{\mathrm{a}}$ & $42.7 \pm 4.5^{b}$ & $<0.0001$ \\
\hline \multirow[t]{4}{*}{ Aftertaste } & Aftertaste strength & The strength of the overall aftertaste & $17.9 \pm 3.3^{b}$ & $38.1 \pm 4.0^{\mathrm{a}}$ & $23.7 \pm 5.1^{b}$ & $38.2 \pm 3.6^{\mathrm{a}}$ & $<0.0001$ \\
\hline & Metallic & Iron (II) sulphate heptahydrate $(0.0036 \mathrm{~g} / \mathrm{L})$ & $4.9 \pm 3.3^{b}$ & $3.3 \pm 4.7^{\mathrm{b}}$ & $9.2 \pm 5.8^{\mathrm{a}}$ & $5.7 \pm 5.2^{\mathrm{a}, \mathrm{b}}$ & 0.02 \\
\hline & Vanilla & Vanilla extract (Nielsen-Massey) & $1.7 \pm 1.1^{\mathrm{b}}$ & $27.4 \pm 4.1^{\mathrm{a}}$ & $0.0 \pm 1.8^{\mathrm{b}}$ & $26.7 \pm 4.8^{\mathrm{a}}$ & $<0.0001$ \\
\hline & Sweet & Sucrose $(5.76 \mathrm{~g} / \mathrm{L})$ & $12.7 \pm 2.2^{b}$ & $35.6 \pm 3.8^{\mathrm{a}}$ & $7.5 \pm 1.9^{b}$ & $34.2 \pm 5.0^{\mathrm{a}}$ & $<0.0001$ \\
\hline
\end{tabular}

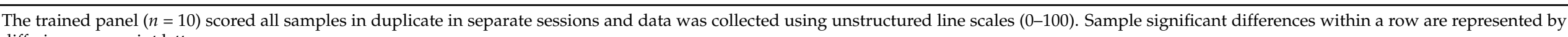
differing superscript letters. 


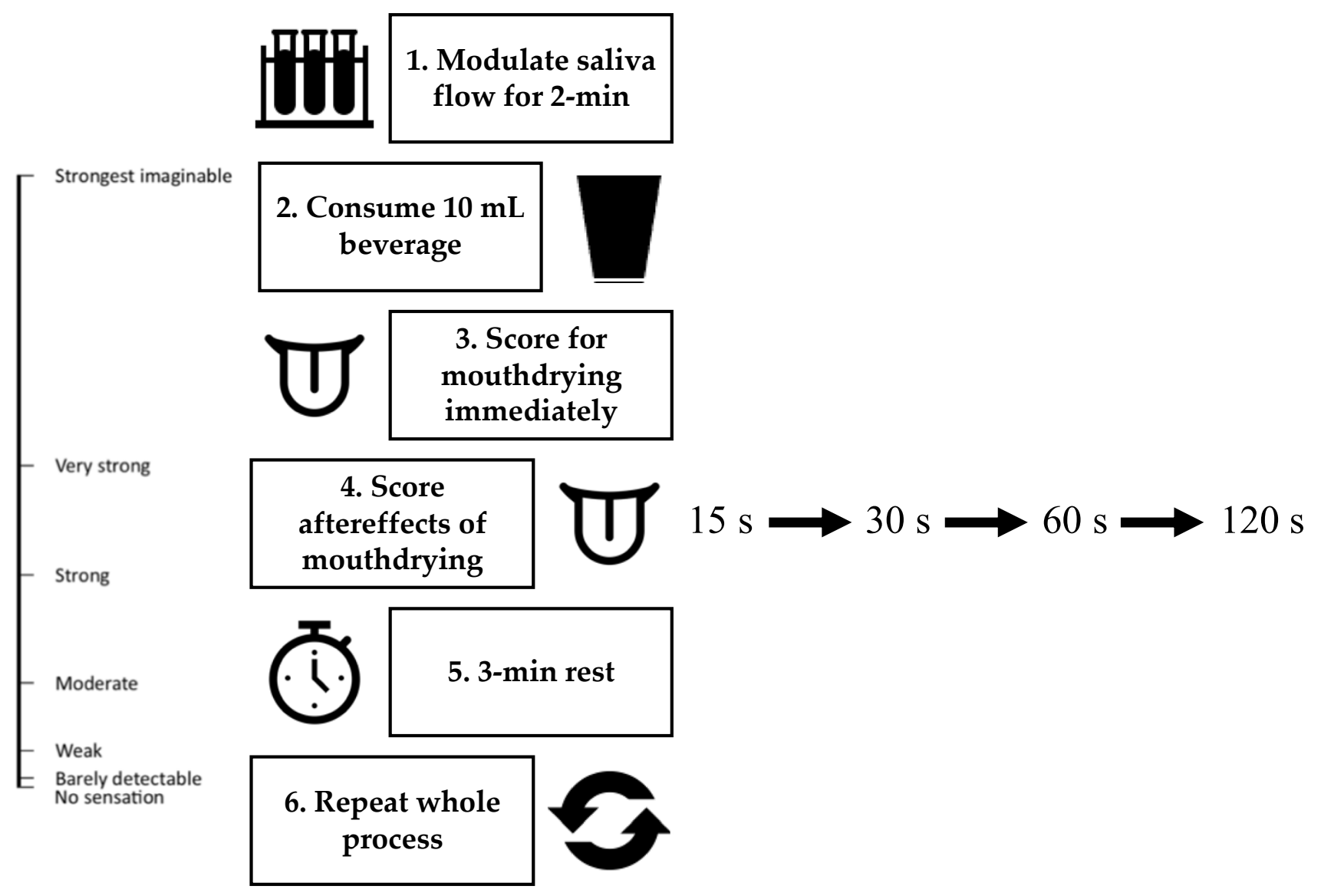

Figure 2. Brief overview of modulating saliva flow and mouthdrying perception protocol.

\subsection{Salivary Flow Rates}

Unstimulated and stimulated saliva were both collected at the beginning of study visit two with a sufficient rest ( 10 $\mathrm{min})$ in between. Saliva collection methods were as outlined in our previous work $[16,19]$. In summary, unstimulated saliva was collected for 5 -min whereas stimulated saliva was collected for 2-min whilst chewing parafilm ${ }^{\circledR}(5 \times 5 \mathrm{~cm})$. Saliva samples were collected in tubes $(60 \mathrm{~mL}$, wide) and flow rates calculated as $\mathrm{mL} / \mathrm{min}$. Samples were stored on ice before analysis.

\subsection{Saliva Samples Post Beverage Consumption and Mouthdrying Perception}

An oral retention method from Norton et al. [19] was developed to measure protein retained in saliva after swallowing, alongside rating of mouthdrying (Figure 3). Stimulated saliva samples were collected (as outlined in Section 2.8) and used as a baseline measurement (rationale based on previous work [19]). Eight beverage samples $(4 \times$ WPeBS and $4 \times$ WPBS; $10 \mathrm{~mL}$ ) were provided at two time points ( $15 \mathrm{~s}$ and $60 \mathrm{~s}$, randomised). These were considered key time points based on previous work [15,19]). Volunteers (on eight occasions) gave four saliva samples and rated four beverages for perceived mouthdrying on a gLMS post beverage consumption. A 5-min break was obligatory between samples to prevent crossover effects and ensure protein concentration in saliva samples had plateaued $[19,46]$. Warm filtered water was consumed to palate cleanse during this break. Tubes were weighed before and after collection to measure saliva weight and all saliva samples were stored on ice pending analysis. 


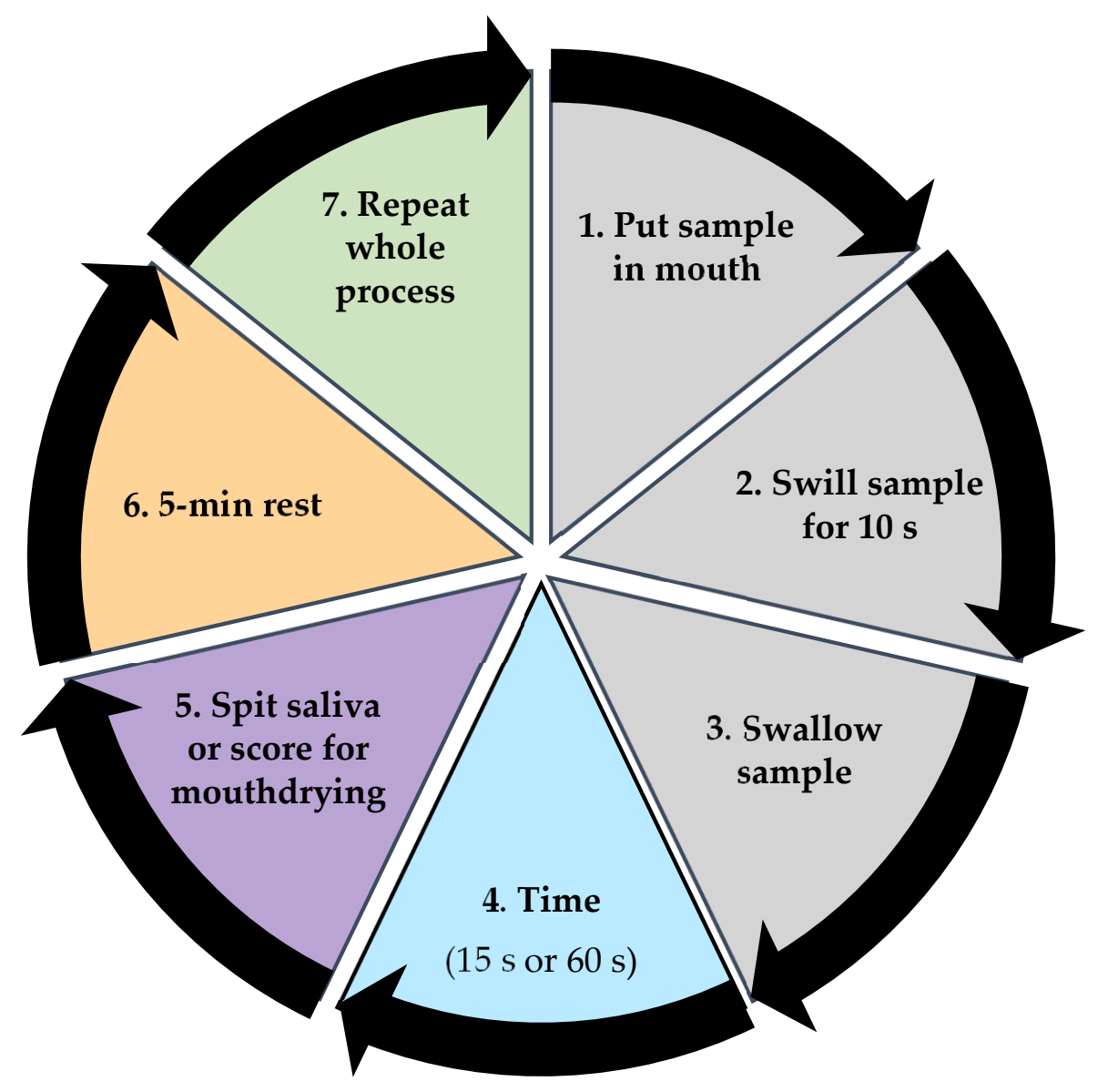

Figure 3. Summary of protocol for saliva sample collection and mouthdrying perception rating post beverage consumption.

\subsection{Protein Analysis of Saliva Samples}

Bradford Assay was used to analyse the protein concentration $(\mathrm{mg} / \mathrm{mL})$ in saliva samples [47,48] as described in Norton et al. [19]. In summary, all analysis was performed in triplicate with biological and analytical replicates. BSA was used as the protein standard (6 dilutions; 0.125 to $2 \mathrm{mg} / \mathrm{mL}$ ). Saliva samples diluted 1:2 (saliva: purified water) and analysis followed immediately after each volunteer's visit. Volunteers baseline values (i.e., protein concentration in stimulated saliva) were subtracted from sample measurements to calculate protein concentration remaining post WPBS consumption. WPeBS was used as a control beverage and as outlined in previous work [19]; the protein concentration was already below the baseline value (i.e., stimulated saliva protein concentration) therefore no additional calculations were required.

\subsection{Statistical Analysis}

Analysis of variance (ANOVA) was used to analyse sensory profile data $[49,50]$ with main effects tested against the sample by assessor interaction, sample fitted as a fixed effect and assessor as a random effect using SenPAQ software (version 5.01, Qi Statistics, Kent, UK). Fisher's least significant difference (LSD) was used to test sample pairs assuming a $5 \%$ significance level.

Mouthdrying 2-AFC data was analysed using Binomial expansion and Thurstonian modelling in V-power to calculate $p$ values, power and d' value [51]. Quantile analysis (based on the median) grouped volunteers into low and high salivary flow rates (XLSTAT version 2020.1.3, Addinsoft, Paris, France). Perception and liking data from volunteers were analysed via linear mixed models using explanatory variables of sample, sex, saliva flow, 
volunteers fitted as a random effect, with the dependent variables of attribute perception, liking and JAR rating scores $\left(\mathrm{SAS}^{\circledR}\right.$ software, version 9.4, Cary, NC, USA, applying Bonferroni). Volunteers modulated saliva flow and mouthdrying perception data were analysed with sample, time, condition, sex, and saliva flow as explanatory variables, volunteers fitted as a random effect, and mouthdrying perception rating as the dependent variable. Salivary flow rates and baseline saliva samples were analysed using explanatory variable of sex, volunteers fitted as a random effect and with the dependent variables of saliva flow and protein concentration respectively. Volunteers saliva samples post beverage consumption and mouthdrying perception data were analysed with the explanatory variables of sample, time, sex, saliva flow, volunteers fitted as random effects and with protein concentration and mouthdrying perception as the dependent variables. All attribute data was collected on the gLMS log-scale and was transformed to linear data (anti-logged). Data reflects least square means (LSM) estimates.

Penalty analysis of the JAR and liking data was carried out (as previously described $[16,19])$ using XLSTAT. Paired preferences were analysed using Binomial expansion in V-Power [51]. It should be noted that only two volunteers were taking medication and therefore outlier analysis was conducted using a Dixon test in XLSTAT. Outlier analysis demonstrated that these volunteers were not considered outliers (except for one volunteer for one output measure (thickness)). Analysis was therefore carried out with and without this volunteer's data, with the overall result being the same and accordingly all data was included within the statistical analysis. Significant differences were defined in all analyses by $p<0.05$.

\section{Results}

\subsection{Sensory Profile}

The sensory profile demonstrated that 12 of the 21 attributes were significantly different $(p<0.05)$ between samples as outlined in Table 3. In summary, it demonstrated whey protein beverages (WPB and WPBS) significantly increased mouthdrying, chalky and body compared with whey permeate beverages (WPeB and WPeBS). Adding sucrose and vanilla to beverages (WPeBS and WPBS) resulted in significantly increased sweet and vanilla notes compared with $\mathrm{WPeB}$ and WPB, as well as significantly reduced mouthdrying in WPBS compared with WPB, therefore improving sample palatability.

\subsection{Mouthdrying 2-Alterative Forced Choice Test (2-AFC)}

The mouthdrying paired comparison test demonstrated that WPBS was significantly more mouthdrying ( $p<0.0001$; $\mathrm{d}^{\prime}$ value: 1.19 ; power: 0.99$)$ compared with WPeBS; $60 \%$ of the volunteers were able to distinguish that WPBS was more mouthdrying.

\subsection{Whey Beverage Individual Perception and Liking}

Volunteers perceived WPBS as significantly $(p<0.05)$ more mouthdrying, thicker, less sweet and less easy to consume compared with WPeBS (Figures 4 and 5). There was no significant difference $(p=0.53)$ in liking between whey beverages with both beverages perceived, on average, as neither like nor dislike on a 9-point hedonic scale. There was also no significant difference in Just-About-Right flavour and thickness between whey beverages, where both were perceived as closer to Just-About-Right (JAR =3) compared with too weak/thin for flavour and thickness respectively (Table 4). Saliva flow had no significant effect on whey beverage liking, perception, easiness to consume or JAR attributes, whether it was tested as overall or by grouping volunteers into low and high saliva flow (Table S1). There was also no significant effect of sex on whey beverage individual perception and liking (Table S1). 


\section{gLMS Descriptors}

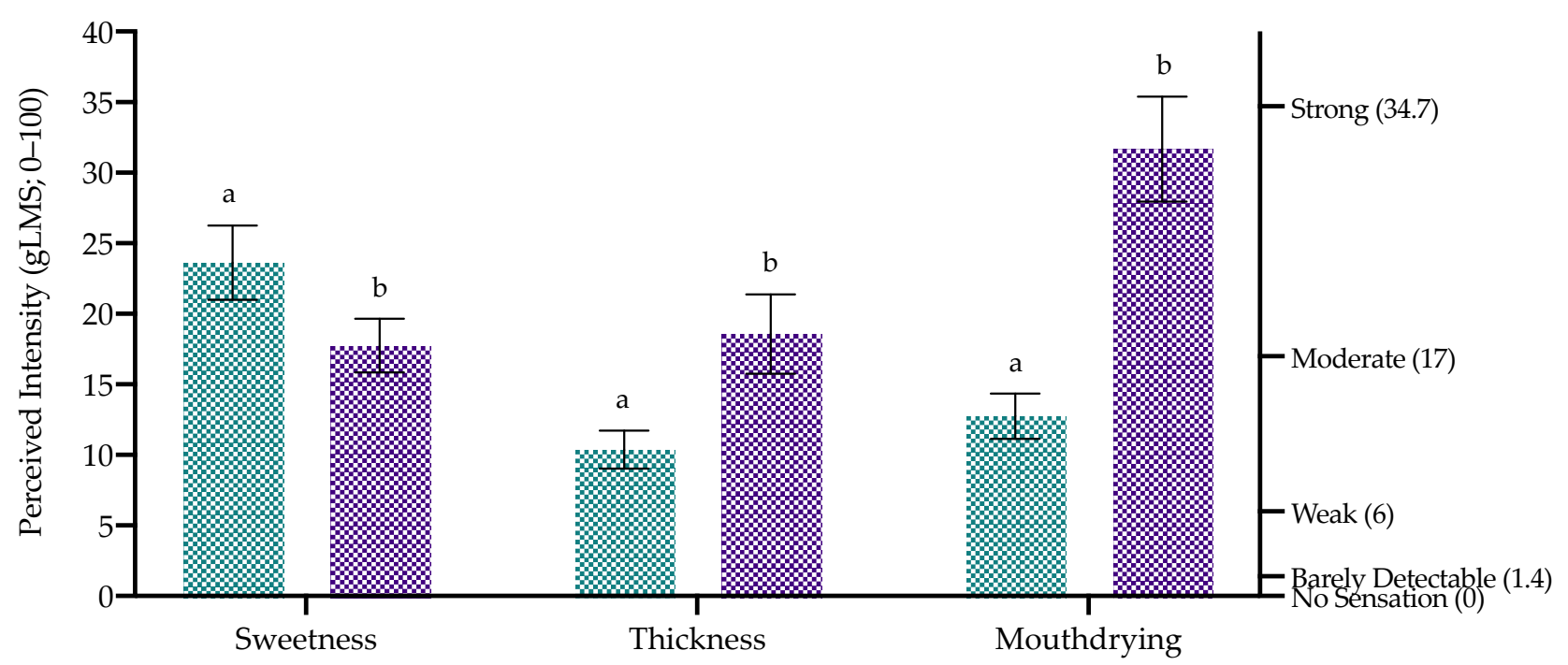

Attribute Perception Descriptors

Whey Permeate Beverage Sweetened $\%$ Whey Protein Beverage Sweetened

Figure 4. Volunteers' attribute perception mean ratings ( \pm standard error) of whey beverages $(n=40$; anti-logged data). Sample significant differences denoted by differing small letters.

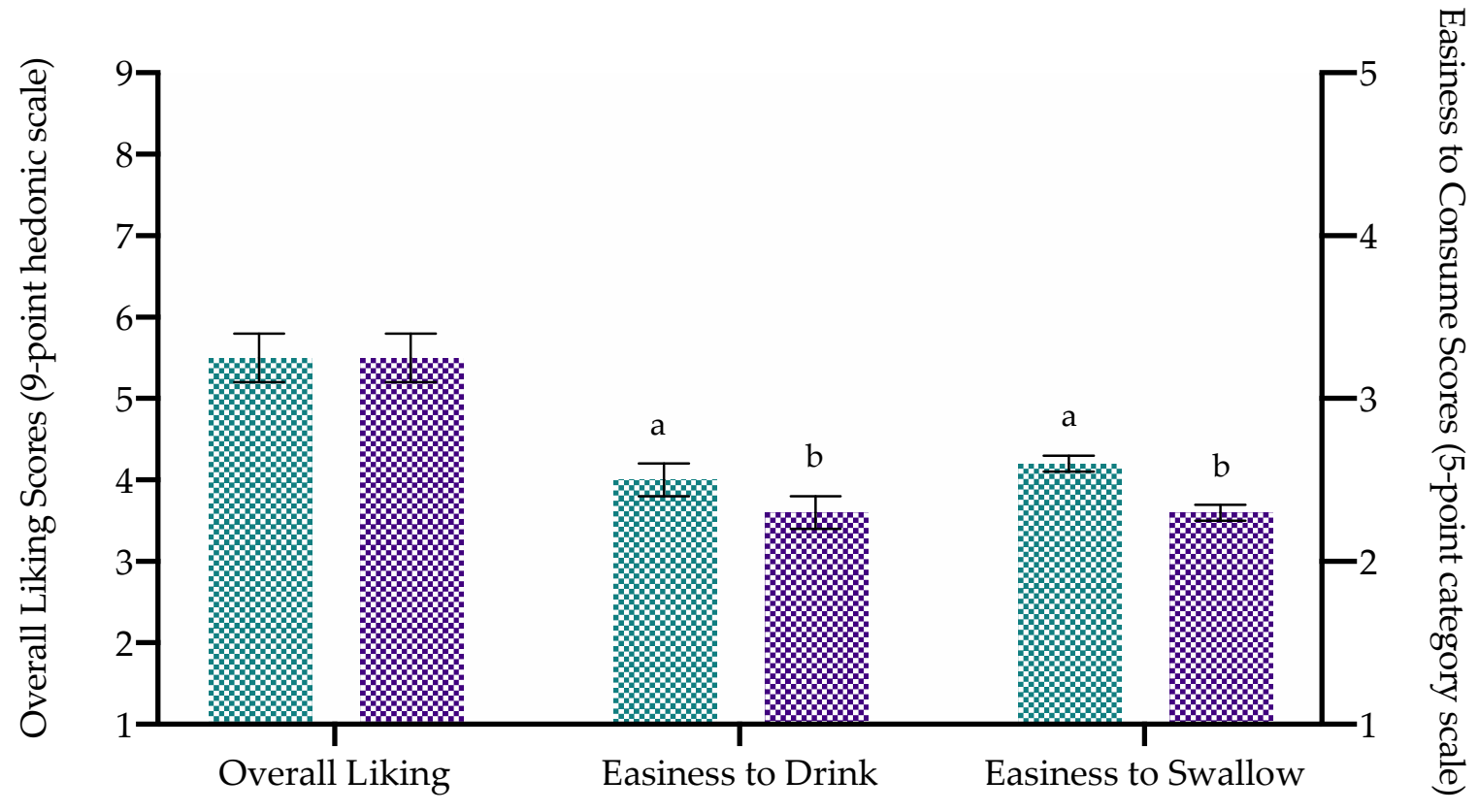

Liking and Easiness to Consume Descriptors

Whey Permeate Beverage Sweetened $\%$ Whey Protein Beverage Sweetened

Figure 5. Volunteers' liking (left axis; measured on a 9-point hedonic scale) and easiness to consume (drink or swallow) (right axis; measured on a 5-point category scale) mean ratings ( \pm standard error) of whey beverages $(n=40)$. Sample significant differences denoted by differing small letters. 
Table 4. Mean Just-About-Right (JAR) ratings and subsequent influence on liking ratings (penalty analysis) (WPeBS: whey permeate beverage sweetened; WPBS: whey protein beverage sweetened).

\begin{tabular}{|c|c|c|c|c|c|c|}
\hline & \multirow{3}{*}{ Overall $(n=40)$} & \multirow{3}{*}{$\begin{array}{l}\text { Significance of Sample } \\
\text { ( } p \text { Value })\end{array}$} & \multicolumn{4}{|c|}{ Penalty Analysis } \\
\hline & & & \multicolumn{2}{|c|}{ Too Little } & \multicolumn{2}{|c|}{ Too Much } \\
\hline & & & Mean Drop & Frequency (\%) & Mean Drop & Frequency $(\%)$ \\
\hline \multicolumn{7}{|c|}{ JAR Flavour } \\
\hline WPeBS & $2.8 \pm 0.1$ & \multirow{2}{*}{0.82} & $1.48 \#$ & 25 & 1.21 & 15 \\
\hline WPBS & $2.9 \pm 0.1$ & & $1.34 \#$ & 25 & 2.54 & 15 \\
\hline \multicolumn{7}{|c|}{ JAR Thickness } \\
\hline WPeBS & $2.6 \pm 0.1$ & \multirow{2}{*}{0.17} & 0.11 & 48 & $-1.18 *$ & 5 \\
\hline WPBS & $2.8 \pm 0.1$ & & 0.71 & 35 & $3.40 *$ & 13 \\
\hline
\end{tabular}

\# represents a significant difference $(p<0.05)$ within a sample in liking compared with mean liking rating, where the sample was considered Just-About-Right; * denotes size of the group lower than $20 \%$ of population. Frequency (\%) is the $\%$ of volunteers within each group (too little or too much).

There was no significant difference $(p=0.13)$ in preference between whey beverages. However, this study successfully demonstrated improvements in sample palatability compared with previous samples, as WPeBS and WPBS were both significantly preferred $(p<0.0001)$ compared with WPeB and WPBS (Table 5). Where attributes are not at the optimum level for a volunteer (as reflected in Just-About-Right, JAR, ratings) this may impact liking. The penalty analysis (Table 4) concluded liking was negatively impacted where flavour was considered too low. Volunteers generally provided positive feedback for flavour and texture of both beverages; 86 comments were provided of which 53 were positive and 33 were negative (Table 6).

Table 5. Volunteers' counts of whey beverage preference (WPeB: whey permeate beverage; WPeBS: whey permeate beverage sweetened; WPB: whey protein beverage; WPBS: whey protein beverage sweetened).

\begin{tabular}{cccc}
\hline Pair Number & Sample & Preference & $\begin{array}{c}\text { Significance of Sample } \\
(\boldsymbol{p} \text { Value })\end{array}$ \\
\hline 1 & WPeBS & 24 & \\
1 & WPBS & 16 & 0.13 \\
2 & WPB & 5 & $<0.0001$ \\
2 & WPBS & 35 & $<0.0001$ \\
3 & WPeB & 5 & \\
3 & WPeBS & 35 & \\
\hline
\end{tabular}

Table 6. Examples of volunteers' comments relating to whey beverages (WPeBS: whey permeate beverage sweetened; WPBS: whey protein beverage sweetened).

\begin{tabular}{cc}
\hline Sample & Comments and Volunteers Details \\
\hline WPeBS & $\begin{array}{c}\text { "Thin, almost like drinking water (v2, female, aged 28). Nice sweet taste, } \\
\text { but not too strong (v4, male, aged 26). There wasn't much flavour to detect } \\
\text { (v6, female, aged 25). Texture was OK (v9, female, aged 21)" } \\
\text { "Very soothing (v1, male, aged 27). Smooth texture, bit mouthdrying (v4, } \\
\text { male, aged 26). It is quite powdery (v7, female, aged 24). A bit too watery } \\
\text { and thin (v30, male, aged 19)" }\end{array}$ \\
\hline
\end{tabular}

\subsection{Modulating Saliva Flow and Mouthdrying Perception}

Modulating saliva flow led to no significant change $(p=0.96)$ in perceived mouthdrying, as mouthdrying perception remained relatively consistent within each beverage type (Figure 6). In common with the results where saliva was not modulated, there was a significant effect of sample $(p<0.0001)$ where WPBS was more mouthdrying compared with WPeBS at all timepoints $(0 \mathrm{~s}, 15 \mathrm{~s}, 30 \mathrm{~s}, 60 \mathrm{~s}$ and $120 \mathrm{~s})$ (Figure 6). Time also had an overall significant effect $(p=0.0002)$ where perceived mouthdrying slightly increased over 
time (Figure 6). There was no significant effect of saliva flow and sex on mouthdrying perception following modulated saliva flow (Figure S3).

\section{gLMS Descriptors}
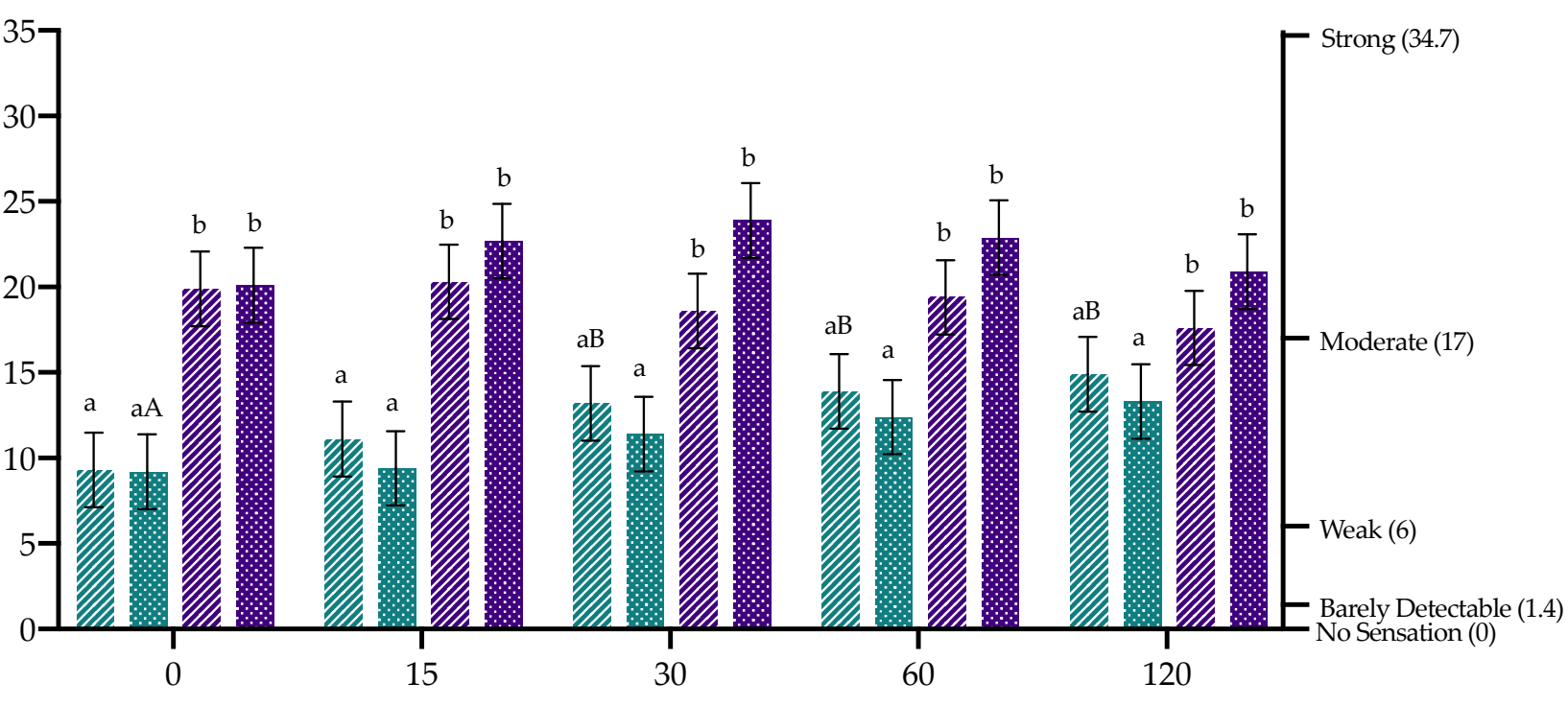

Time (s)

Figure 6. Volunteers' perceived mouthdrying ( \pm standard error) post beverage (WPeBS: whey permeate beverage sweetened; WPBS: whey protein beverage sweetened) consumption over time following saliva flow (SF) being modulated (increased: chewing on parafilm and decreased: by placing cotton wool rolls within the mouth). Sample significant differences are represented by differing small letters (between samples) and capital letters (within samples).

\subsection{Salivary Flow Rates}

Unstimulated salivary flow rates was $0.72 \pm 0.04 \mathrm{~mL} / \mathrm{min}$, whereas stimulated flow was $2.29 \pm 0.11 \mathrm{~mL} / \mathrm{min}$. Volunteers were also categorised by quantile analysis into low and high salivary flow rates (Table 1). There was no significant effect of sex (unstimulated saliva flow (USF): $p=0.15$ and stimulated saliva flow (SSF): $p=0.053$ ) on saliva flow regardless of collection method. However, there was a tendency for males to have a higher salivary flow compared with females (USF: males $0.81 \pm 0.09$ and females $0.68 \pm 0.05 \mathrm{~mL} / \mathrm{min}$ and SSF: males $2.61 \pm 0.20$ and females $2.15 \pm 0.13 \mathrm{~mL} / \mathrm{min}$ ).

\subsection{Saliva Samples Post Beverage Consumption and Mouthdrying Perception}

WPBS led to a significantly higher protein concentration $(p<0.001)$ in saliva samples post swallow compared with WPeBS at both timepoints (15 s and $60 \mathrm{~s}$ ) (Figure 7). There was no significant effect of time overall on protein concentration in saliva samples post beverage consumption $(p=0.052)$, however, there was a significant time by sample interaction $(p=0.03)$. Pairwise comparison highlighted that WPBS consumption resulted in saliva samples showing a significantly higher $(p=0.003)$ protein content at $15 \mathrm{~s}$ compared with $60 \mathrm{~s}$, whereas WPeBS had a lower saliva protein content across all timepoints $(p=0.83)$ (Figure 7). Results from the saliva samples post beverage consumption supported the mouthdrying perception results, where WPBS resulted in significantly higher mouthdrying scores $(p<0.001)$ compared with WPeBS at both timepoints (Figure 7). However, there was no overall significant effect of time $(p=0.26)$ on perceived mouthdrying where WPBS decreased very slightly over time whereas WPeBS remained relatively consistent (Figure 7). There were no significant effects of protein concentration in saliva samples and mouthdrying perception relating to sex or saliva flow (Figure S4). 


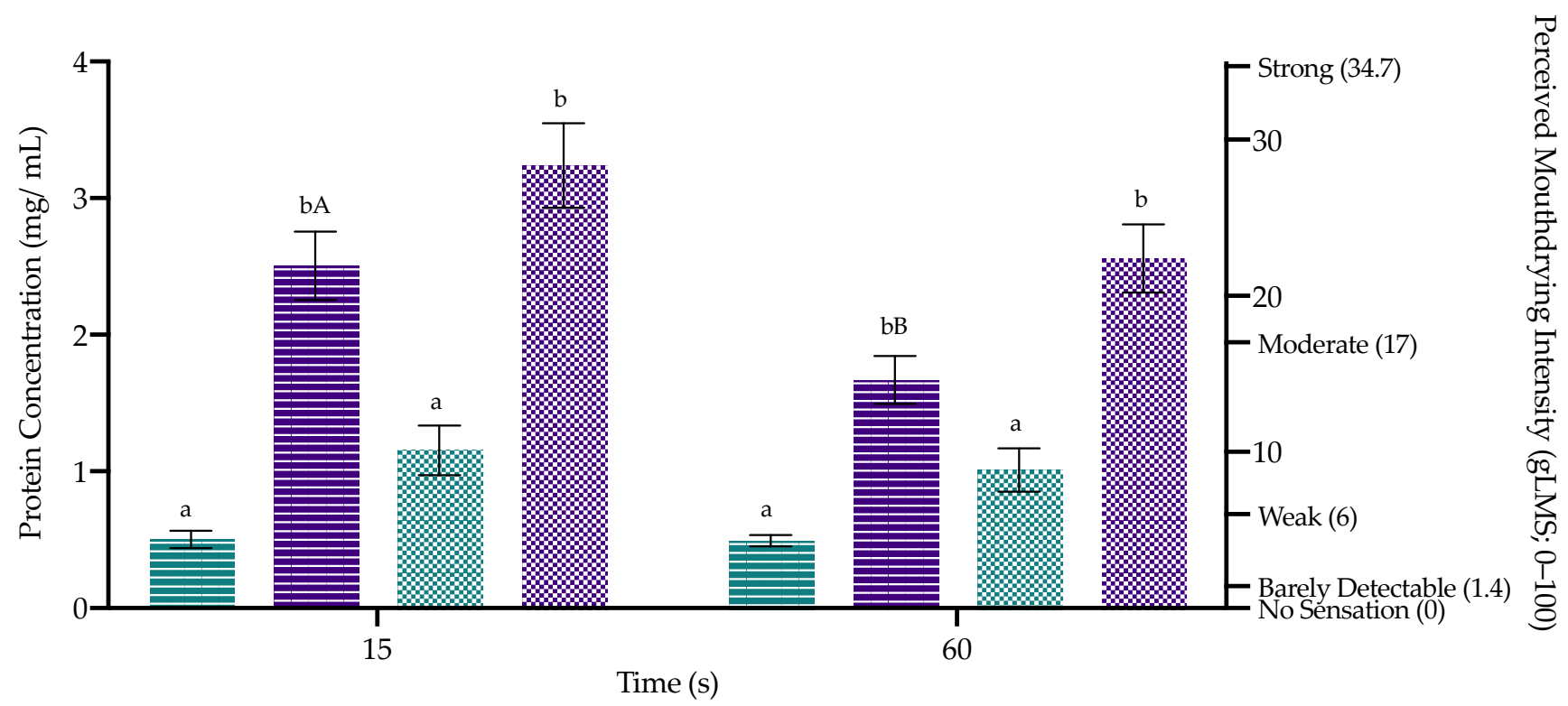

$\equiv$ SSPBC WPeBS $\equiv$ SSPBC WPBS $\%$ Mouthdrying WPeBS $\%$ Mouthdrying WPBS

Figure 7. Protein concentration in saliva samples post beverage consumption (SSPBC) (left axis) and perceived mouthdrying (right axis; measured on gLMS (0-100)) ( \pm standard error). WPeBS: whey permeate beverage sweetened and WPBS: whey protein beverage sweetened. Sample significant differences are represented by differing small letters (between samples) and capital letters (within samples).

\section{Discussion}

\subsection{Sensory Profile and Whey Beverage Individual Perception and Liking}

Fortifying beverages with whey protein increased mouthdrying, chalky, thickness, body and reduced sweetness and easiness to consume compared with a non-protein control (in this case a whey permeate beverage (WPeB)). These findings support previous work in this area that WPBs are associated with mouthdrying, mouthcoating and chalky attributes [14,15]. These studies were however carried out without a non-protein control, therefore our study concluded that it is indeed the protein in WPBs, rather than other constituents of whey, that cause mouthdrying within WPBs. Previous research highlighted the lack of sensitivity of a gLMS (0-100) compared with a 2-AFC in detecting mouthdrying in older adults $[19,36]$. Accordingly, to address these concerns, our study also measured mouthdrying using a paired comparison test to a ensure differences between samples were not missed on a gLMS (0-100), which can occur if samples are presented monadically [52]. The 2-AFC clearly demonstrated the majority of the volunteers (32 out of 40) supported WPBS as being more mouthdrying compared with WPeBS. Therefore, our study proved volunteers perceived WPBS as more mouthdrying compared with WPeBS (by both gLMS and 2-AFC), which was additionally supported by the trained panel findings. A limitation of our study was not being able to recruit older adults due to the ongoing COVID-19 pandemic. Accordingly, next steps should include future work with older adults to prove conclusively that sensitivity to mouthdrying increases with age, using a more sensitive discrimination test (i.e., 2-AFC) in different food matrices.

Previous work by Norton et al. [19] demonstrated low liking scores by volunteers for model WPBs, therefore this study added sucrose and vanilla to improve potentially flavour and acceptability. The sensory profile concluded that adding sucrose and vanilla increased sweet and vanilla notes, which subsequently reduced perception of mouthdrying. This did lead to an improvement in volunteers' liking ratings and a clear preference for the 'improved beverages'. The addition of sucrose and flavour led to increased product acceptance and reduced perceived mouthdrying such additions are commonly found in commercial oral nutritional supplements (ONS). However, the sweetened WPB (WPBS) 
was still mouthdrying and further mitigation may lead to increased palatability. This could maximise product benefits, especially as these products are most often consumed by older adults who may be more sensitive to the products oral adhesion [19] and mouthdrying [36].

It was hypothesised that WPBs would cause mouthdrying, thereby reducing beverage acceptability. However, surprisingly, there was no difference in liking or preference between the two beverages (WPeBS and WPBS). This could be explained by the WPeBS where volunteers lack familiarity with the product and highlighted its minimal flavour, watery, thin and sweet nature, as demonstrated by volunteers consumption habits, penalty analysis and comments. These findings were also supported by the trained panel who identified sweet and vanilla taste, as well as being lower in cooked notes (such as cooked milk and butter) in the WPeBs compared with WPBs. Furthermore, sweetness and thickness are considered key drivers of acceptability in milk beverages [53], which could explain the relatively low liking scores and no difference in liking or preference between the beverages demonstrated in our study.

The sensory profile demonstrated that the WPBS had more body compared with the WPeBS and this result was matched by the volunteers who also perceived WPBS to be thicker. Although the viscosity of the beverages was considered to be broadly similar (Figure S1), there was a mean difference of $0.83 \mathrm{mPaS}$ at $50 \mathrm{~s}^{-1}$ (a commonly cited oral shear rate) [54]. A previous study has shown the Weber fraction (K) for oral thickness perception of model beverages to be 0.26 [55], and therefore with the WPBS thickness at $1.78 \mathrm{mPas}$, the calculated just noticeable difference (JND) would be $0.46 \mathrm{mPas}$. Hence the literature supports that there would be a perceptual difference in thickness between the WPeBS and WPBS. However, a previous study measuring astringency of low $\mathrm{pH}$ WPBs used maltodextrin to modify viscosity (1.6 to $7.7 \mathrm{mPAS}$ ) and found it had no effect on perceived astringency [56]. This supports our current study in that the noticeable difference in thickness is unlikely to have influenced perception of mouthdrying, however the previous study utilised a low $\mathrm{pH}$ whey model, where it is likely that the mechanism of astringency was different to the mechanism of mouthdrying proposed in our neutral $\mathrm{pH}$ samples (mucoadhesion) $[15,19]$. Therefore, it is advisable that future work aims to ensure viscosity is fully matched between beverages (potentially by using hydrocolloids). However, it may be challenging to match such low viscosities and in addition the use of hydrocolloids may potentially alter taste, flavour and mouthfeel properties [26] and lead to a different viscosity response to shear, compared with the viscosity profile resulting from protein.

\subsection{Modulating Saliva Flow and Mouthdrying Perception}

There are numerous key functions associated with saliva [27] and saliva can influence sensory perception. Therefore, it was hypothesised that modulating salivary flow by either decreasing or increasing saliva flow would alter mouthdrying perception. However, no changes in mouthdrying perception were demonstrated immediately post beverage consumption nor over time (as evidenced from the aftereffects) as a result of modulating saliva flow. These findings support previous work which has demonstrated no, or only a minimal, effect of saliva flow on perception of other sensory attributes. For example, modifying salivary flow rates (unstimulated saliva flow and stimulated saliva flow using odour, parafilm and citric acid) had no effect on sensory ratings (8 attributes: flavour (vanilla, bitter/chemical), mouthfeel (temperature, thickness, melting, creaminess) and afterfeel (fat, astringent) of custard desserts [57]. In addition, artificially increasing saliva (by adding saliva related fluids to the product) had minimal effect on sensory perception (apart from increasing melting and decreasing thickness, creaminess and fatty afterfeel sensations) of custard desserts [30]. Therefore, neither different salivary flow rates nor artificially increasing saliva volume had previously resulted in substantial differences in sensory perception in semi solid foods. Salivary composition (total protein concentration and amylase activity) has been shown to alter texture perception of custard desserts \& mayonnaise [58]. However, more recently, Crawford and Running [59] demonstrated 
changes in salivary proteins (proline-rich proteins and cystatins) had only minimal effects on the sensory perception of chocolate milks. Vandenberghe-Descamps et al. [29] also demonstrated very few effects from differences in saliva flow on perception; they proposed that individuals may adapt their food oral processing to compensate for differences in saliva flow status and which may result in little impact on subsequent perception.

Within plant derived food models (such as tea and wine), saliva is considered to influence astringency perception. For example, volunteers with low salivary flow rates perceived wines to be more astringent over a longer duration compared with those with higher salivary flow rates [32]. Whereas after consuming black tea, perceived astringency has been shown to increase with decreasing saliva flow (by washing with water) and decrease with increasing saliva flow (by chewing on parafilm) [31]. However, these findings were not demonstrated in our study using whey beverages; this is likely to be as a result of the different mechanism involved in astringency (i.e., polyphenols binding to salivary proteins) compared with mouthdrying in neutral $\mathrm{pH}$ beverage (i.e., oral retention or mucoadhesion) and accordingly mechanisms may respond differently to salivary flow rate.

In addition, our study decreased saliva flow by using cotton wool rolls within the mouth (rather than washing with water) to replicate the 'dry' feeling within the mouth (a method successfully utilised previously by Brunstrom et al. [45]). Such findings could suggest the role of saliva flow on sensory perception is potentially food model specific and dependent on the underlying mechanism responsible for the mouthdrying sensation. Accordingly, further research is necessary to understand the role of saliva flow on mouthdrying perception in whey protein food models as current research has resulted in minimal differences so far. This could relate to how studies have measured or modulated saliva flow and is therefore potentially not a true reflection of natural variation in saliva.

\subsection{Saliva Samples Post Beverage Consumption and Mouthdrying Perception}

Whey protein adhered to the oral cavity (oral retention as a marker of mucoadhesion) post WPBS to a greater extent compared with WPeBS, supporting previous work in this area [19]. Furthermore, our study demonstrated that perceived mouthdrying was significantly increased following WPBS consumption compared with WPeBS, which matched the oral retention results. Retention declined over time, however, this trend was not matched by perceived mouthdrying which did not reduce significantly over time. Previously, a build-up of whey protein derived mouthdrying was suggested to be as a result of a possible mucoadhesion mechanism $[15,19,46,60]$. Mucoadhesion within a WPB is considered to be as a result of the following potential mechanisms [61]:

(1) movement of the sample in the mouth provides a greater surface area for whey protein to adhere to the oral cavity;

(2) spreading and swelling on the oral mucosa leads to increased adhesion and stronger adhesive joint via different physiochemical interactions [22,25];

(3) mucoadhesion is considered to result from a prolonged oral exposure and loss of saliva lubrication and increased friction, tissue exposure, adhesion and interaction $[46,62]$ can result in perceived mouthdrying potentially caused by mucoadhesion.

Therefore, our study reinforces the suggestion that mucoadhesion could be a cause of whey protein derived mouthdrying, as this study measured for the first time both oral retention of protein and mouthdrying within the same protocol and demonstrated both increased retention and perceived mouthdrying following WPB consumption. This study aimed to quantify mouthdrying using a 'physical measure' (i.e., retention as a measure of mucoadhesion) at the same time as scoring mouthdrying perception within WPBs, as no previous study to our knowledge has investigated this. Typically, correlations are found in the literature between potential mechanisms and sensory data and this can result in an inability to prove relationships which should be a key priority for ongoing research. Future work however remains necessary to prove mucoadhesion is the cause of the oral retention and to demonstrate that a reduction in retention would lead to a subsequent decrease in perceived mouthdrying. 


\section{Conclusions}

This study demonstrated by using three different methods (QDA, 2-AFC and gLMS) that WPBs were significantly more mouthdrying compared with WPeBs. In addition, increasing sweetness in WPBs significantly reduced perceived mouthdrying and increased consumer preference. Such results suggest improving mouthfeel attributes associated with WPBs could be a key strategy to improve compliance and product suitability for older adults. This study was unable to demonstrate a role of saliva flow on mouthdrying perception. However further research using improved methodology that captures the natural variation in saliva flow is needed to understand better the impact of salivary flow changes on mouthdrying perception in whey protein food models. Previously, mucoadhesion had been considered as a probable cause of whey protein derived mouthdrying and our study highlighted WPB consumption significantly increased oral retention of the protein, which coincided with perceived mouthdrying. Hence, we conclude that whey protein is the cause of WPB retention and mouthdrying. Mucoadhesion is the probable cause of whey protein derived mouthdrying and oral retention provides a physical measure of perceived mouthdrying. However, it still needs further proof that modulating retention would result in changes in perceived mouthdrying. Understanding such mechanisms could result in improved products and increased consumption, this is important as protein consumption is associated with numerous benefits. There is a growing emphasis on improving protein intake across the lifespan to enhance health outcomes and given the potential importance of WPBs in achieving this, they must have high palatability to promote consumption and maximise the benefits from protein products.

Supplementary Materials: The following are available online at https:/ /www.mdpi.com/2304-815 8/10/3/587/s1, Figure S1: Viscosity of whey beverages. Figure S2: Summary of volunteers $(n=40)$ gLMS (generalised Labelled Magnitude Scale) familiarisation questions. Table S1: Additional factors (such as sex and saliva flow) influencing volunteers $(n=40)$ liking, effort to consume, attribute perception and appropriateness of attribute level (Just-About-Right, JAR) mean ratings of whey beverages. Figure S3. Additional factors influencing volunteers $(n=40)$ modulating saliva flow perceived mouthdrying. Table S2: Summary of baseline protein concentration $(\mathrm{mg} / \mathrm{mL})$ in saliva samples. Figure S4a. Additional factors influencing protein concentration in saliva samples post beverage consumption. Figure S4b. Additional factors influencing volunteers $(n=40)$ perceived mouthdrying.

Author Contributions: Conceptualization, V.N., L.M. and S.L.; methodology, V.N., L.M., S.L.; software, V.N., L.M. and S.L.; validation, V.N., L.M. and S.L.; formal analysis, V.N.; investigation, V.N.; resources, V.N.; data curation, V.N.; writing-original draft preparation, V.N.; Writing-Review and editing, V.N., L.M., S.L.; supervision, L.M., S.L., V.N.; project administration, V.N., L.M. and S.L. All authors have read and agreed to the published version of the manuscript.

Funding: This research received no external funding.

Institutional Review Board Statement: The study was conducted according to the guidelines of the Declaration of Helsinki, and approved by the School of Chemistry, Food and Pharmacy Ethics Committee of University of Reading (study number: 32/20 and date of approval: 13 July 2020).

Informed Consent Statement: Informed consent was obtained from all volunteers involved in the study.

Data Availability Statement: The data presented in this study is available on request from the corresponding author. The data will be deposited in the University of Reading Research Data Archive on completion of V.N. PhD thesis.

Acknowledgments: We are grateful to Volac International Ltd. for providing the whey powders, our volunteers for their participation and Julia Rodriguez Garcia and Rui Ding for their advice with the viscosity measurements.

Conflicts of Interest: The authors declare no conflict of interest. 


\section{References}

1. Bauer, J.; Biolo, G.; Cederholm, T.; Cesari, M.; Cruz-Jentoft, A.J.; Morley, J.E.; Philips, S.; Sieber, C.; Stehle, P.; Teta, D.; et al. Evidence based recommendation for optimal dietary protein intake in older people: A position paper from the PROT-AGE study group. JAMA 2013, 14, 542-559. [CrossRef] [PubMed]

2. Department of Health. 1991. Available online: https://assets.publishing.service.gov.uk/government/uploads/system/uploads/ attachment_data/file/743790/Dietary_Reference_Values_-_A_Guide_1991_.pdf (accessed on 4 January 2019).

3. Stevenson, E.J.; Watson, A.W.; Brunstrom, J.M.; Corfe, B.M.; Green, M.A.; Johnstone, A.M.; Williams, E.A. Protein for life: Towards a focussed dietary framework for healthy ageing. Nutr. Bull. 2018, 43, 97-102. [CrossRef]

4. Stevenson, E.; Brunstrom, J.; Johnstone, A.; Green, M.; Williams, L.; Corfe, B. Protein for Life Team. 2019. Available online: https:/ / ktn-uk.co.uk/news/protein-for-life-a-framework-for-action (accessed on 20 July 2019).

5. Philips, S.M.; Chevalier, S.; Leidy, H.J. Protein 'requirements' beyond the RDA: Implications for optimisizing health. Appl. Physiol. Nutr. Metab. 2015, 41, 565-572. [CrossRef]

6. Pennings, B.; Boirie, Y.; Senden, J.M.; Gijsen, A.P.; Kuipers, H.; van Loon, L.J. Whey protein stimulates postprandial muscle protein accretion more effectively than do casein and casein hydrolysate in older men. Am. J. Clin. Nutr. 2011, 93, 997-1005. [CrossRef]

7. Nieuwenhuizen, W.F.; Weenen, H.; Rigby, P.; Hetherington, M.M. Older adults and patients in need of nutritional support: Review of current treatment options and factors influencing nutritional intake. Clin. Nutr. 2010, 29, 160-169. [CrossRef] [PubMed]

8. Hubbard, G.P.; Elia, M.; Holdoway, A.; Stratton, R.J. A systematic review of compliance to oral nutritional supplements. Clin. Nutr. 2012, 31, 293-312. [CrossRef]

9. Gosney, M. Are we wasting our money on food supplements in elder care wards? J. Adv. Nurs. 2003, 43, 275-280. [CrossRef]

10. Szczesniak, A.S.; Kahn, E.L. Consumer awareness of and attitudes to food texture I: Adults. J. Texture Stud. 1971, 2, 280-295. [CrossRef] [PubMed]

11. Methven, L.; Rahelu, K.; Economou, N.; Kinneavy, L.; Ladbrooke-Davis, L.; Kennedy, O.B.; Mottram, D.S.; Gosney, M.A. The effect of consumption volume of profile and liking of oral nutritional supplements of varied sweetness: Sequential profiling and boredom tests. Food Qual. Prefer. 2010, 21, 948-955. [CrossRef]

12. Thomas, A.; van der Stelt, A.J.; Prokop, J.; Lawlor, J.B.; Schlich, P. Alternating temporal dominance of sensations and liking scales during the intake of a full portion of an oral nutritional supplement. Food Qual. Prefer. 2016, 53, 159-167. [CrossRef]

13. Thomas, A.; van der Stelt, A.J.; Schlich, P.; Lawlor, J.B. Temporal drivers of liking for oral nutritional supplements for older adults throughout the day with monitoring of hunger and thirst status. Food Qual. Prefer. 2018, 70, 40-48. [CrossRef]

14. Withers, C.A.; Lewis, M.J.; Gosney, M.A.; Methven, L. Potential sources of mouth drying in beverages fortified with dairy proteins: A comparison of casein- and whey-rich ingredients. J. Dairy Sci. 2014, 97, 1233-1247. [CrossRef]

15. Bull, S.P.; Hong, Y.; Khutoryanskiy, V.V.; Parker, J.K.; Faka, M.; Methven, L. Whey protein mouth drying influenced by thermal denaturation. Food Qual. Prefer. 2017, 56, 233-240. [CrossRef] [PubMed]

16. Norton, V.; Lignou, S.; Bull, S.P.; Gosney, M.A.; Methven, L. Consistent effects of whey protein fortification on consumer perception and liking of solid food matrices (cakes and biscuits) regardless of age and saliva flow. Foods 2020, 9, 1328. [CrossRef]

17. Tsikritzi, R.; Wang, J.; Collins, V.J.; Allen, V.J.; Mavrommatis, Y.; Moynihan, P.J.; Gosney, M.A.; Kennedy, O.B.; Methven, L. The effect of nutrient fortification of sauces on product stability, sensory properties, and subsequent liking by older adults. J. Food Sci. 2015, 80, 1100-1110. [CrossRef]

18. Tsikritzi, R.; Moynihan, P.J.; Gosney, M.A.; Allen, V.J.; Methven, L. The effect of macro- and micro-nutrient fortification of biscuits on their sensory properties and on hedonic liking of older people. J. Sci. Food Agric. 2014, 94, 2040-2048. [CrossRef] [PubMed]

19. Norton, V.; Lignou, S.; Bull, S.P.; Gosney, M.A.; Methven, L. An investigation of the influence of age and saliva flow on the oral retention of whey protein and its potential effect on the perception and acceptance of whey protein beverages. Nutrients 2020, 12, 2506. [CrossRef]

20. Lemieux, L.; Simard, R.E. Astringency, a textural defect in dairy products. Lait 1994, 74, 217-240. [CrossRef]

21. ASTM E253-20. Available online: http:/ / www.astm.org/cgi-bin/resolver.cgi?E253 (accessed on 1 July 2020).

22. Smart, J.D. The basics and underlying mechanisms of mucoadhesion. Adv. Drug Deliv. Rev. 2005, 57, 1556-1568. [CrossRef] [PubMed]

23. Andrews, G.P.; Laverty, T.P.; Jones, D.S. Mucoadhesive polymeric platforms for controlled drug delivery. Eur. J. Pharm. Biopharm. 2009, 71, 505-518. [CrossRef]

24. Carvalho, F.C.; Bruschi, M.L.; Evangelista, R.C.; Gremiao, M.P.D. Mucoadhesive drug delivery systems. Braz. J. Pharm. Sci. 2010, 46, 1-17. [CrossRef]

25. Khutoryanskiy, V.V. Advances in mucoadhesion and mucoadhesive polymers. Macromol. Biosci. 2011, 11, 748-764. [CrossRef]

26. Cook, S.L.; Bull, S.P.; Methven, L.; Parker, J.K.; Khutoryanskiy, V.V. Mucoadhesion: A food perspective. Food Hydrocoll. 2017, 72, 281-296. [CrossRef]

27. Carpenter, G.H. The secretion, components, and properties of saliva. Annu. Rev. Food Sci. Technol. 2013, 4, 267-276. [CrossRef] [PubMed]

28. Vandenberghe-Descamps, M.; Laboure, H.; Prot, A.; Septier, C.; Tournier, C.; Feron, G.; Sulmont-Rosse, C. Salivary flow decreases in healthy elderly people independently of dental status and drug intake. J. Texture Stud. 2016, 47, 353-360. [CrossRef] 
29. Vandenberghe-Descamps, M.; Sulmont-Rosse, C.; Septier, C.; Feron, G.; Laboure, H. Using food comfortability to compare foods sensory characteristics expectations of elderly people with or without oral health problems. J. Texture Stud. 2017, 48, $280-287$. [CrossRef]

30. Engelen, L.; de Wijk, R.A.; Prinz, J.F.; Janssen, A.M.; van der Bilt, A.; Weenen, H.; Bosman, F. A comparison of the effects of added saliva, amylase and water on texture perception in semisolids. Physiol. Behav. 2003, 78, 805-811. [CrossRef]

31. Nayak, A.; Carpenter, G.H. A physiological model of tea-induced astringency. Physiol. Behav. 2008, 95, 290-294. [CrossRef] [PubMed]

32. Fischer, U.; Boulton, R.B.; Noble, A.C. Physiological factors contributing to the variability of sensory assessments: Relationship between salivary flow rate and temporal perception of gustatory stimuli. Food Qual. Prefer. 1994, 5, 55-64. [CrossRef]

33. Mosca, A.C.; Chen, J. Food-saliva interactions: Mechanisms and implications. Trends Food Sci. Technol. 2017, 66, 125-134. [CrossRef]

34. Munoz-Gonzalez, C.; Feron, G.; Canon, F. Main effects of human saliva on flavour perception and the potential contribution to food consumption. Proc. Nutr. Soc. 2018, 77, 423-431. [CrossRef]

35. Kelly, M.; Vardhanabhuti, B.; Luck, P.; Drake, M.A.; Osborne, J.; Foegeding, E.A. Role of protein concentration and protein-saliva interactions in the astringency of whey proteins at low pH. J. Dairy Sci. 2010, 93, 1900-1909. [CrossRef]

36. Withers, C.; Gosney, M.A.; Methven, L. Perception of thickness, mouth coating and mouth drying of dairy beverages by younger and older volunteers. J. Sens. Stud. 2013, 28, 230-237. [CrossRef]

37. Luiking, Y.C.; Deutz, N.E.P.; Memelink, R.G.; Verlaan, S.; Wolfe, R.R. Postprandial muscle protein synthesis is higher after a high whey protein, leucine enriched supplement than after a dairy like product in healthy older people: A randomised controlled trial. Nutr. J. 2014, 13, 9. [CrossRef] [PubMed]

38. Buzalaf, M.A.R.; Hannas, A.R.; Kato, M.T. Saliva and dental erosion. J. Appl. Oral Sci. 2012, 20, 493-502. [CrossRef]

39. Belitz, H.D.; Grosch, W.; Schieberle, P. Food Chemistry, 3rd ed.; Springer: Berlin/Heidelberg, Germany, 2004 ; pp. $245-339$.

40. Stone, H.; Sidel, J.; Oliver, R.S.; Woolsey, A.; Singleton, R.C. Sensory evaluation by quantitative descriptive analysis. Food Technol. 1974, 28, 24-34.

41. International Organisation for Standardization. Sensory Analysis_Methodology_Paired Comparison Test. ISO Standard No. 5495. 2005. Available online: https://www.iso.org/standard/31621.html (accessed on 1 July 2020).

42. Adjei, M.Y.B. Applications and limitations of discrimination testing. In Discrimination Testing in Sensory Science: A Practical Handbook; Rogers, L., Ed.; Woodhead Publishing: Cambridge, UK, 2017; pp. 85-105.

43. Hayes, J.E.; Allen, L.; Bennett, S. Direct comparison of the generalized visual analog scale (gVAS) and general labeled magnitude scale (gLMS). Food Qual. Prefer. 2013, 28, 36-44. [CrossRef] [PubMed]

44. Bartoshuk, L.M.; Duffy, V.B.; Green, B.G.; Hoffman, H.J.; Ko, C.-W.; Lucchina, L.A.; Marks, L.E.; Snyder, D.J.; Weiffenbach, J.M. Valid across-group comparisons with labeled scales: The gLMS versus magnitude matching. Physiol. Behav. 2004, 82, 109-114. [CrossRef]

45. Brunstrom, J.M.; Macrae, A.W.; Roberts, B. Mouth-state dependent changes in the judged pleasantness of water at different temperatures. Physiol. Behav. 1997, 61, 667-669. [CrossRef]

46. Bull, S.P.; Khutoryanskiy, V.V.; Parker, J.K.; Faka, M.; Methven, L. Oral retention of whey protein: Measurement and mechanisms. Food Chem. 2020. submitted.

47. Bradford, M.M. A rapid and sensitive method for the quantitation of microgram quantities of protein utilizing the principle of protein-dye binding. Anal. Biochem. 1976, 72, 248-254. [CrossRef]

48. Zor, T.; Selinger, Z. Linerization of the Bradford protein assay increases its sensitivity: Theoretical and experimental studies. Anal. Biochem. 1996, 236, 302-308. [CrossRef]

49. Hasted, A. Statistical analysis of descriptive data. In Descriptive Analysis in Sensory Evaluation; Kemp, S.E., Hort, J., Hollowood, T., Eds.; Wiley-Blackwell: West Sussex, UK, 2018; pp. 165-213.

50. Lawless, H.T.; Heymann, H. Sensory Evaluation of Food_Principles and Practices, 2nd ed.; Springer: New York, NY, USA, 2010; pp. 227-253.

51. Ennis, J.M.; Jesionka, V. The power of sensory discrimination methods revisited. J. Sens. Stud. 2011, 26, 371-382. [CrossRef]

52. Zhou, X.; Shen, Y.; Parker, J.K.; Kennedy, O.B.; Methven, L. Relative effects of sensory modalities and importance of fatty acid sensitivity on fat perception in a real food model. Chem. Percept. 2016, 9, 105-119. [CrossRef]

53. Villegas, B.; Tarrega, A.; Carbonell, I.; Costell, E. Optimising acceptability of new prebiotic low-fat milk beverages. Food Qual. Prefer. 2010, 21, 234-242. [CrossRef]

54. National dysphagia diet task force. National Dysphagia Diet: Standardisation for Optimal Care; American Dietetic Association: Chicago, IL, USA, 2002; pp. 1-43.

55. Camacho, S.; Dop, M.; de Graaf, C.; Stieger, M. Just noticeable differences and weber fraction of oral thickness perception of model beverages. J. Food Sci. 2015, 80, S1583-S1588. [CrossRef]

56. Beecher, J.W.; Drake, M.A.; Luck, P.J.; Foegeding, E.A. Factors regulating astringency of whey protein beverages. J. Dairy Sci. 2008, 91, 2553-2560. [CrossRef]

57. Engelen, L.; de Wijk, R.A.; Prinz, J.F.; van der Bilt, A.; Bosman, F. The relation between saliva flow after different stimulations and the perception of flavor and texture attributes in custard desserts. Physiol. Behav. 2003, 78, 165-169. [CrossRef] 
58. Engelen, L.; van den Keybus, P.A.M.; de Wijk, R.A.; Veerman, E.C.I.; Nieuw Amerongen, A.V.; Bosman, F.; Prinz, J.F.; van der Bilt, A. The effect of saliva composition on texture perception of semi-solids. Arch. Oral Biol. 2007, 52, 518-525. [CrossRef]

59. Crawford, C.R.; Running, C.A. Addition of chocolate milk to diet corresponds to protein concentration changes in human saliva. Physiol. Behav. 2020, 225, 113080. [CrossRef]

60. Withers, C.A.; Cook, M.T.; Methven, L.; Gosney, M.A.; Khutoryanskiy, V.V. Investigation of milk proteins binding to the oral mucosa. Food Funct. 2013, 4, 1668-1674. [CrossRef]

61. Norton, V.; Lignou, S.; Methven, L. Influence of age and individual differences on mouthfeel perception of whey protein fortified products: A review. Foods 2021, 10, 433. [CrossRef]

62. Vardhanabhuti, B.; Cox, P.W.; Norton, I.T.; Foegeding, E.A. Lubricating properties of human whole saliva as affected by beta-lactoglobulin. Food Hydrocoll. 2011, 25, 1499-1506. [CrossRef] 